Article

\title{
Evolution of Soot Particle Number, Mass and Size Distribution along the Exhaust Line of a Heavy-Duty Engine Fueled with Compressed Natural Gas
}

\author{
Elia Distaso* ${ }^{\mathbb{D}}$, Riccardo Amirante $\mathbb{D}$, Giuseppe Calò, Pietro De Palma $\mathbb{D}^{\mathbb{D}}$ and Paolo Tamburrano \\ Department of Mechanics, Mathematics and Management, Politecnico di Bari, 70126 Bari, Italy; \\ riccardo.amirante@poliba.it (R.A.); giuseppe.calo@poliba.it (G.C.); pietro.depalma@poliba.it (P.D.P.); \\ paolo.tamburrano@poliba.it (P.T.) \\ * Correspondence: elia.distaso@poliba.it
}

Received: 27 June 2020; Accepted: 22 July 2020; Published: 3 August 2020

check for updates

\begin{abstract}
An experimental study has been conducted to provide a characterization of the transformations that particle size distributions and the number density of soot particles can encounter along the exhaust line of a modern EURO VI compliant heavy-duty engine, fueled with compressed natural gas. Being aware of the particles history in the exhausts can be of utmost importance to understand soot formation and oxidation dynamics, so that, new strategies for further reducing these emissions can be formulated and present and future regulations met. To this purpose, particle samples were collected from several points along the exhaust pipe, namely upstream and downstream of each device the exhaust gases interact with. The engine was turbocharged and equipped with a two-stage after-treatment system. The measurements were carried out in steady conditions while the engine operated in stoichiometric conditions. Particle emissions were measured using a fast-response particle size spectrometer (DMS500) so that size information was analyzed in the range between 5 and $1000 \mathrm{~nm}$. Particle mass information was derived from size distribution data using a correlation available in the literature. The reported results provide more insight on the particle emission process related to natural gas engines and, in particular, point out the effects that the turbine and the after-treatment devices produce on soot particles. Furthermore, the reported observations suggest that soot particles might not derive only from the fuel, namely, external sources, such as lubricant oil, might have a relevant role in soot formation.
\end{abstract}

Keywords: soot emissions; particle number; particle mass; particle size distribution; compressed natural gas engines; heavy-duty engines

\section{Introduction}

Recently, many governments around the world have announced their willingness to ban internal combustion engines (ICEs) in a short amount of time. This might suggest that the era of the ICEs has come to an end. Nevertheless, several concerns have been raised about the feasibility to power the entire transportation sector with electricity, especially regarding the land and marine commercial vehicles [1-4]. Although touted as the only possible solution to zero-emissions transport, electric-based mobility does not come without its own set of side effects [5-7].

The strong limitations related to batteries' energy density and cost make full electrification actually convenient only for small passenger cars $[2,8,9]$. Moreover, the absence of tailpipe emissions brings the large part of benefits in urban areas (if electricity is generated sufficiently far from the urban center). For commercial transport, full electrification is not practical or even desirable at the moment, because it would reduce the capacity of the truck to carry goods and increase the costs [2]. Due to the high 
energy density of petroleum fuels, the range autonomy of the vehicles powered with ICEs is essentially limited by the driver rather than by the engine itself. Modern heavy-duty trucks might reach a range of 1000 miles [8], meaning $20 \mathrm{~h}$ of continuous driving at an average speed of $50 \mathrm{mph}$. A battery pack able to ensure half of this autonomy, i.e., 500 miles, would need a capacity of at least $1100 \mathrm{kWh}$ [10], resulting 4 times heavier than a typical diesel engine for such a truck, costing more than the truck itself and requiring $12 \mathrm{~h}$ to charge [2]. In contrast, a more concrete option for commercial transport in the future might rely on the electrification of the roads, with the so-called e-highways [9]. However, such a solution demands the construction of dedicated infrastructures, and it might still require the presence of an ICE for the non-electrified road segments.

Future developments in the transportation sector will be necessarily driven by a mix of technologies, and ICEs will have a role $[1-4,8,9,11]$. It becomes imperative to keep improving these engines, which are not the same as fifty years ago, as often mistakenly believed. Innovation has been constantly brought in the automotive industry as a response to increasingly stringent government regulations $[1,3,8,11-15]$. Innovative combustion concepts [16-21] and new emerging control strategies [22-26] can certainly offer plenty of scope for improvement. In addition, research dedicated to developing low-carbon and alternative fuels is also increasing [2,27]. The fact that ICEs fueled with either gasoline or diesel represent the largest share of today's market does not necessarily mean that the situation will remain unchanged in the future. Natural gas represents one of the most concrete alternatives, [27-30] and its use is increasingly promoted in transport both for energy security and local air quality reasons [2,27]. Although in some Countries it is extensively used in passenger cars, natural gas is mainly used in commercial transport.

The absence of large hydrocarbon chains and aromatics [31-33] makes natural gas a fuel cleaner than gasoline or diesel and able to guarantee lower gaseous emissions [32,34,35]. However, despite particle mass (PM) formation is small, the number concentrations of particles emitted by compressed natural gas (CNG) engines are not negligible when compared to those of Diesel engines [31,36,37]. Moreover, it has been pointed out that particles emitted from natural gas engine falls mainly within the ultrafine size range [37-41], highlighting a harmful potential that requires additional research [42,43]. Several studies have reported that particle formation in CNG engines depends upon driving parameters $[37,44,45]$ and fuel composition $[31,34,41,46]$. However, the predominance of ultrafine particles is essentially attributed to lubricant oil [37,38,43,47-49], since it is detectable in the exhaust in the form of metal traces deriving from the additives pack $[49,50]$. Other recent works have highlighted that CNG engines emit the largest amounts of particles during acceleration, especially after a long idling period [37,51-54], and that these peaks are made up entirely by ultrafine particles [52-54], suggesting that lubricant oil infusion could be favored in such phases.

Lubricant oil can either directly reach the combustion chamber or can be released into the exhaust and the intake manifolds, contributing differently to the shape of particle size distribution (PSD), as demonstrated in a recent work [38]. The long hydrocarbon chains constituting lubricant oil can enhance soot precursor formation in the combustion chamber and can undergo pyrolysis or partial oxidation in the exhaust gases $[55,56]$. These findings suggest that soot emissions recorded after the exhaust gases have been discharged from the engine can differ substantially from those generated in the combustion chamber. External sources along the exhaust line (i.e., the turbocharger bearings lubricating circuit) can contribute to increase the number of particles emitted. Furthermore, the devices with which the exhaust gases interact before being discharged from the engine can alter the PSD function, affecting the final particle number $(\mathrm{PN})$ and particle mass (PM). It is well known that exhaust after-treatment systems have non-negligible effects on soot particles [56-60]. A three-way catalytic converter (TWC) reduces gaseous emissions at an acceptable level, but dedicated research is still needed for better understanding its effects on soot emissions, since contradictory results have been reported [57-61]. The efficiency of the TWC strongly depends on the temperature [62,63] and this can directly influence the behavior with respect to soot interactions. 
The aim of the present work is to highlight the transformations that the PSD and, consequently, the total PN and PM can undergo along the exhaust line of a turbocharged heavy-duty CNG engine. Namely, the objective is to ascertain the effects produced by the interactions between the exhaust gases and each of the devices mounted on the engine exhaust line. A fast-response differential mobility spectrometer was used to sample directly from raw, upstream and downstream of the turbine and of each of the two catalysis stages.

\section{Materials and Methods}

\subsection{Experimental Apparatus}

The experimental campaign was carried out on a heavy-duty Euro VI CNG engine. It was selected for the present analysis because representative of the latest generation of the heavy-duty CNG engine technology. It was a production engine and it was tested with no modifications. The main specifications of the engine are reported in Table 1 . The engine had 4 cylinders and 4 valves per cylinder. It was equipped with an electronically driven high-pressure injection system, based on a multipoint sequential phased injection strategy. It was turbocharged and equipped with a two-stage aftertreatment system composed of a close-coupled pre-catalyst and an underfloor TWC.

Table 1. Main specifications of the tested engine.

\begin{aligned} & \hline Displacement $2988 \mathrm{cc} \\ &$ Stroke $104.0 \mathrm{~mm} \\ &$ Bore $95.8 \mathrm{~mm} \\ &$ Compression Ratio $12.5: 1 \\ &$ Maximum Power $100 \mathrm{~kW}$ at $[2730 \div 3500] \mathrm{rpm} \\ &$ Maximum Torque $350 \mathrm{Nm}$ at $[1500 \div 2730] \mathrm{rpm} \\ &$\hline\end{aligned}

A fast-response Differential Mobility Spectrometer Cambustion DMS500 was used throughout the experimental campaign for sampling directly from the exhaust line. Its operation is based on the electrical mobility and it was used to measure PN concentrations and PSD functions, from 5 to $1000 \mathrm{~nm}$, at $10 \mathrm{~Hz}$. The DMS500 is equipped with a built-in two-stage dilution system specifically for direct engine exhaust measurements. The first dilution stage at the sampling point avoids condensation and agglomeration, while the second diluter is employed for sampling from a wide range of concentrations. A $1.5 \mathrm{~m}$ heated line was used for sampling the engine exhausts in order to avoid condensation of combustion water.

\subsection{Experimental Procedure}

The schematic diagram of the experimental setup is depicted in Figure 1, in which the sampling points located along the exhaust line are highlighted by means of green circles. Temperature was measured at each of these points in order to ascertain possible influences that changes of the thermodynamic conditions along the exhaust line can have on particle emissions.

The considered engine was the subject of a recent work [44], in which its entire operating range was characterized in terms of PN emissions (the engine speed was varied from 800 to $3500 \mathrm{rpm}$ and the engine load from $20 \%$ to $100 \%$ of the full load). Although the results showed that particle emission levels increased with engine load and speed, the highest value did not correspond to the maximum engine speed and load. Namely, the highest PN levels were recorded for engine loads comprise between $70 \%$ and $80 \%$ and engine speeds between $65 \%$ and $80 \%$ of the corresponding maximum values. Therefore, an engine speed of $2500 \mathrm{rpm}$ and $80 \%$ of the full load were considered as operating conditions, because they are deemed as the most representative in terms of soot emissions for the purpose of the present work, which extends the analysis of particle emissions to the entire exhaust line. 


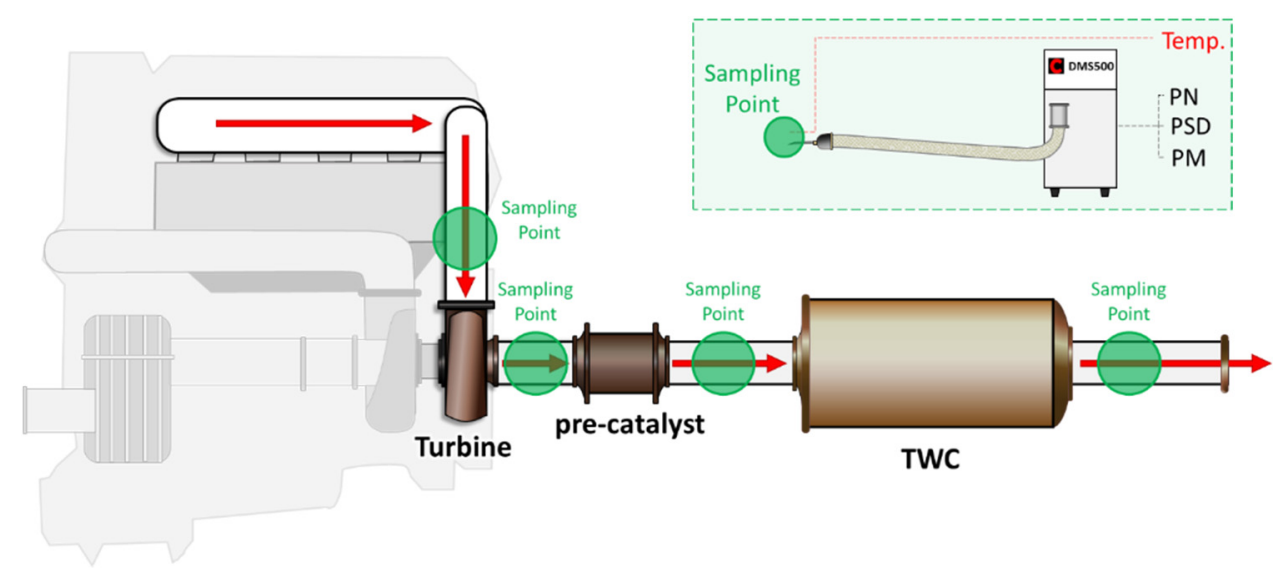

Figure 1. Experimental apparatus.

To ensure proper operation and reliable response of the particulate analyzers, the engine was first warmed up at $1500 \mathrm{rpm}$. The selected operating conditions were then reached, and data were recorded after a stabilization period. A sampling time of about $1.5 \mathrm{~min}$ was chosen for ensuring good statistics and accounting for the presence of occasional spikes in the emitted particles per minute that the present engine showed [44] and that characterize soot emissions of SI engines in general [64].

\subsection{Data Reduction}

The PSD functions were provided by the sampling instrument in terms of normalized concentration $d N / d \log D_{p} / \mathrm{cm}^{3}$, in which $d N$ is the number of particles in the instrument channel width $D_{p}$, and $d \log D_{p}$, is the difference in the $\log$ of the channel width. Throughout this work, PN data are expressed in terms of particles $/ \mathrm{kWh}$, for generality, which means that the $d N / d \log D_{p} / \mathrm{cm}^{3}$ data were post-processed by considering the values measured for the exhaust mass flow rate, the engine torque and speed, and considering that the instrument had a resolution of 16 channels per decade.

PM information was derived from the particle size and number data, and its value is reported in the present work with respect to the mass of fuel, namely in $\mathrm{g} / \mathrm{kg}_{f u e l}$. The approach proposed by Maricq and $\mathrm{Xu}$ [65] was considered in order to take into account the fractal structure of soot particle clusters deriving from the agglomeration of spherical carbonaceous primary particles. Given the size distribution, $N\left(D_{p}\right)$, the corresponding total PM can be expressed in terms of the soot particle mobility volume, $V\left(D_{p}\right)$, and effective density, $\rho_{e}\left(D_{p}\right)$, (i.e., the soot mass per unit mobility volume) as follows:

$$
P M=\int \rho_{e}\left(D_{p}\right) V\left(D_{p}\right) N\left(D_{p}\right) d D_{p},
$$

where $V\left(D_{p}\right)=\frac{\pi}{6} D_{p}^{3}$; the dependence of the particle effective density on the mobility diameter, $D_{p}$, indicates that the particles exhibit a fractal-like geometry [65-67]. Namely, because of their dendritic structure, the mass of the soot particle agglomerates does not scale as the cube of the diameter, as in the case of convex geometries, but rather as the diameter raised to the power of the fractal dimension, $d_{f}$, according to the following power law:

$$
\rho_{e}\left(D_{p}\right)=\rho_{0}\left(\frac{D_{p}}{D_{0}}\right)^{d_{f}-3},
$$

where $D_{0}$ is the primary particle diameter and $\rho_{0}$ is the primary particle density [65-67]. 
Since the number of size bins in the differential mobility instruments employed in the present work is finite, the integral in Equation (1) can be substituted by a summation extended over the total number of the size bins, $N_{b i n s}$, (i.e., the number of electrometers in the instrument), as:

$$
P M=\sum_{i=1}^{N_{b i n s}} \frac{\pi}{6} \rho_{0} D_{0}{ }^{\left(3-d_{f}\right)}\left(D_{p}^{d_{f}}\right)_{i} N_{i}
$$

in which $N_{i}$ represents the number of particles in the i-th bin corresponding to a mobility diameter $\left(D_{p}\right)_{i}$, and the expressions relative to $\rho_{e}\left(D_{p}\right)$ and $V\left(D_{p}\right)$ were used.

Maricq and $\mathrm{Xu}[65]$ observed that $\rho_{e}$ increases steeply with the decrease of $D_{p}$ until about $50 \mathrm{~nm}$, where it breaks from the power law dependence and then levels out to a value approximatively equal to $1 \mathrm{~g} / \mathrm{cm}^{3}$, and they found that such a trend was independent of the soot source (namely, of considered fuel or vehicle type) $[65,67]$. It follows that the hypothesis of spherical particles having unit density, as in the "standard spherical calibration" of the DMS500, is valid below a certain particle size, while a fractal-like geometry needs to be considered above that. Therefore, as proposed in [66], total PM was evaluated as the sum of the mass of the nucleation mode (NM) particles, $P M_{N U C}$, and the accumulation mode (AM) particles, $P M_{A C C}$, namely:

$$
P M=P M_{N U C}+P M_{A C C}
$$

In particular, it was considered that NM comprises spherical particles $\left(d_{f}^{N u c}=3\right)$ with $D_{p}<50 \mathrm{~nm}$ and having a primary density $\rho_{0}^{N u c}$ of $1 \mathrm{~g} / \mathrm{cm}^{3}$, and that AM comprises particles characterized by a fractal dimension $d_{f}^{A c c}=2.3$, a primary diameter $D_{0}=20 \mathrm{~nm}$ and a primary density a value of $\rho_{0}^{A c c}$ of $2 \mathrm{~g} / \mathrm{cm}^{3}$, as suggested in various literature works [65-69]. Under these hypothesis, dedicated expressions for $P M_{N U C}$ and $P M_{A C C}$ can be derived:

$$
\begin{gathered}
P M_{N U C}=\frac{\pi}{6} \rho_{0}^{N u c} \sum_{i=1}^{N_{b i n s}^{N u c}}\left(\begin{array}{c}
d_{p}^{N u c} \\
D_{f}^{f}
\end{array}\right)_{i} N_{i} \\
P M_{A C C}=\frac{\pi}{6} \rho_{0}^{A c c} D_{0}{ }^{\left(3-d_{f}^{A c c}\right)} \sum_{j=1}^{N_{b i n s}^{A c c}}\left(D_{f}^{d_{f}^{A c c}}\right)_{j} N_{j},
\end{gathered}
$$

where here $N_{b i n s}^{N u c}$ and $N_{b i n s}^{A c c}$ represent the total numbers of size bins corresponding to mobility diameters smaller than $50 \mathrm{~nm}$ and larger than $50 \mathrm{~nm}$, respectively. It follows that Equation (2) can be rewritten as:

$$
P M=\frac{\pi}{6} \rho_{0}^{N u c} \sum_{i=1}^{N_{b u n s}^{N u c}}\left(D_{p}^{d_{f}^{N u c}}\right)_{i} N_{i}+\frac{\pi}{6} \rho_{0}^{A c c} D_{0}{ }^{\left(3-d_{f}^{A c c}\right)} \sum_{j=1}^{N_{b i n s}^{A c c}}\left(D_{p}^{d_{f}^{A c c}}\right)_{j} N_{j} .
$$

Equation (4) represents the form used in the present work for deriving PM values from PSD data provided by the sampling instrument.

Figure 2 highlights the reduced slope of the particle mass curve with respect to the particle diameter after $50 \mathrm{~nm}$, deriving from Equation (4) (solid red line) in comparison to the "standard spherical calibration" of the DMS500 (dashed black line). The values reported in Figure 2 are nondimensionalized with respect to the mass of a spherical particle with unit diameter and density. 


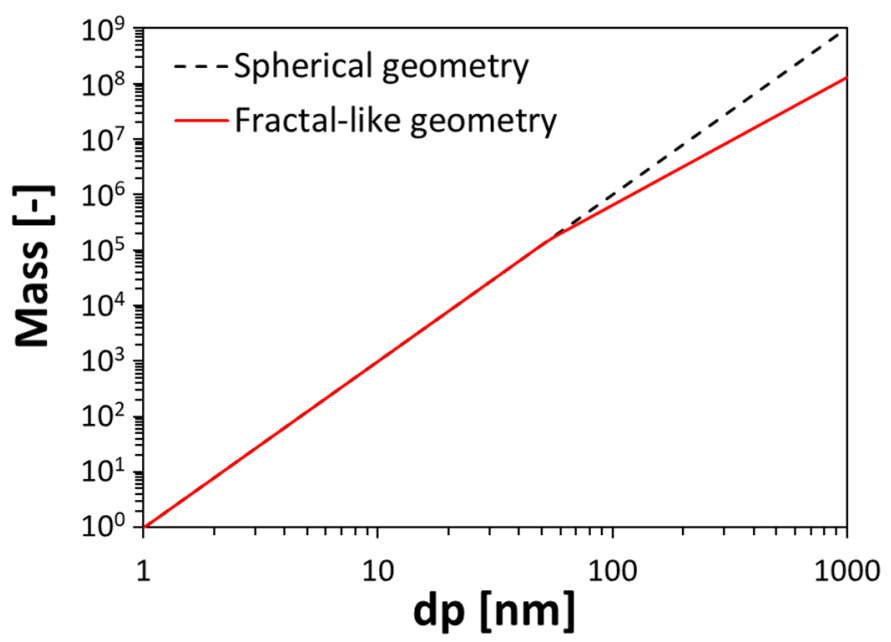

Figure 2. Mass dependence upon the mobility diameter $D_{p}$. Comparison between the "standard spherical calibration", based on the spherical assumption for the particles (dashed black lines) and the expression used in this work, based on a fractal-like geometry (solid red line). The values are nondimensionalized with respect to the mass of a spherical particle having unit diameter and density.

\section{Results}

Along the exhaust line, variations of the temperature and interactions with both the turbine and the after-treatment system produce significative transformations of soot particles, which induce PN and PM variations, as shown in Figures 3 and 4, respectively. Figure 3 shows that total PN increases in the first part of the exhaust line, reaching a peak downstream of the pre-catalyst and then it is significantly reduced by the passage through the TWC. At its peak, PN is roughly two orders of magnitude higher than the value recorded upstream of the turbine. After the TWC, its value returns comparable to the initial value. Figure 4 shows that a trend similar to that of total PN is also recorded for PM. Namely, its highest value is recorded downstream of the pre-catalyst, while a significant reduction is observed after the main catalysis stage. It is worth noting that the TWC abatement action is stronger in terms of PM in comparison to PN. After the TWC, PM levels are the lowest recorded along the exhaust line, being about one order of magnitude lower than those initially observed upstream of the turbine (which are the second lowest ones). This can be explained by considering that larger particles can be more easily oxidized by the passage through the TWC, and particles with larger sizes contribute more significantly to soot mass in comparison to PN. Thus, a variation in the concentration of these particles produces more relevant variations of PM than those of PN values.

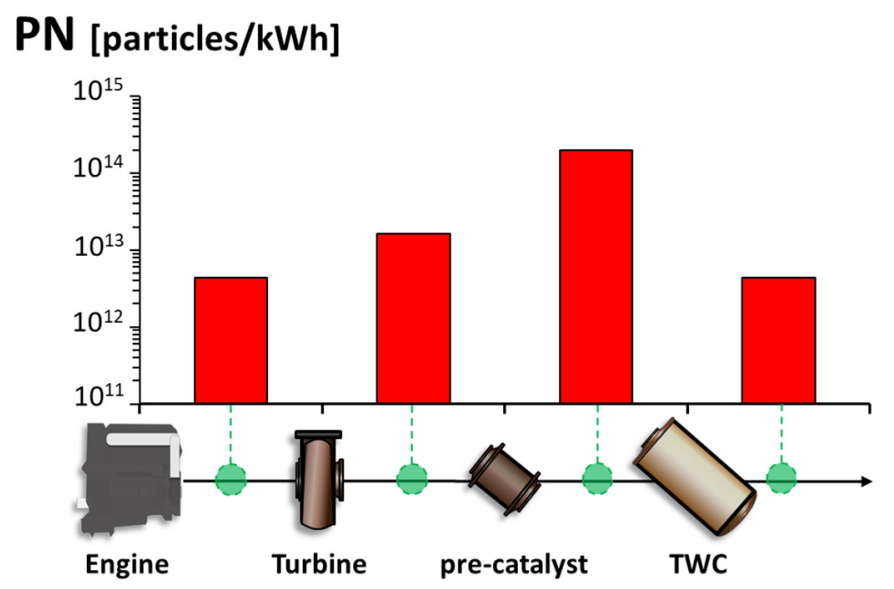

Figure 3. Total PN evolution along the exhaust line. 


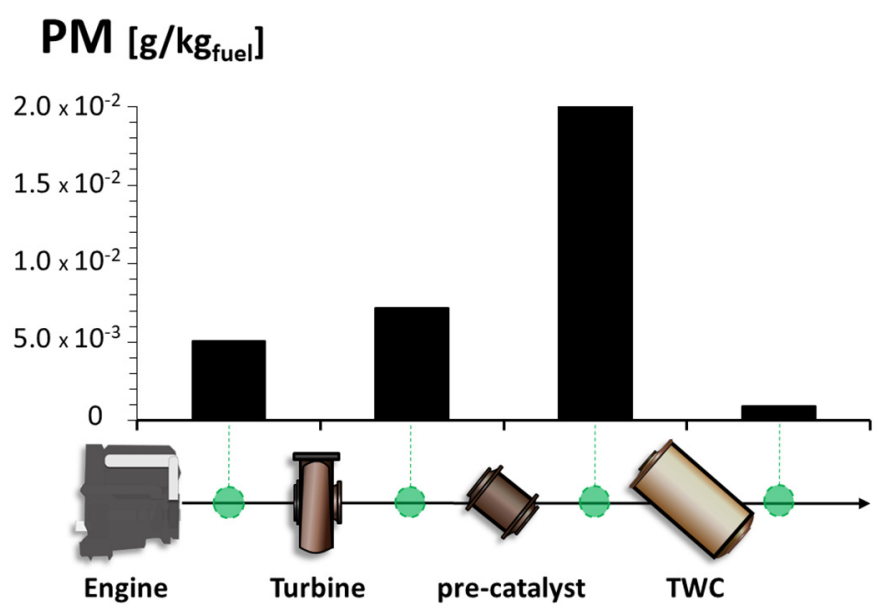

Figure 4. PM evolution along the exhaust line.

In order to highlight that particles having different sizes show different behaviors in traversing the exhaust line, total PN was decomposed in NM and AM fractions, and the result is depicted in Figure 5. This decomposition is well known in the literature, and its results are particularly useful for the analysis, because from the particle size it is possible to infer information about the nature of the particles. Namely, NM comprises particles with size smaller than $50 \mathrm{~nm}$, which are generally considered formed from condensation of volatile material, primarily due to gas-to-particle conversion, whereas AM particles are solid and predominantly carbon-based products of combustion, having size comprised between 50 and $1000 \mathrm{~nm}[40,70]$. Figure 5 shows that the fraction of NM particles increases along the exhaust line. If upstream of the turbine, about $60 \%$ of the particles belongs to the AM; downstream of the TWC, the NM share of PN emissions exceeds $90 \%$. Moreover, it is possible to observe that the total PN peak (located downstream of the pre-catalyst) is characterized by the highest value of the nucleation mode fraction. Downstream of the TWC, although a slight increase of the AM fraction is observed, NM still remains markedly predominant.

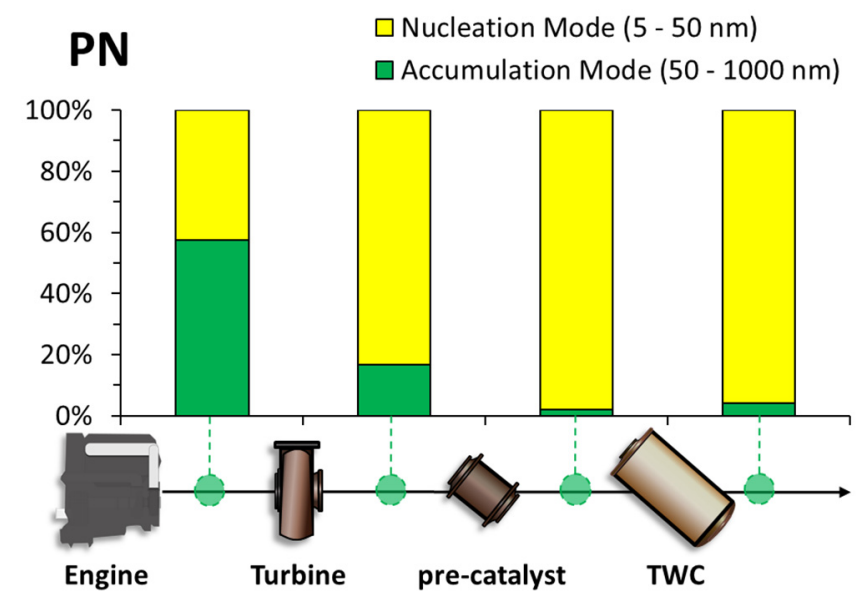

Figure 5. Total PN decomposition in nucleation mode (NM) and accumulation mode (AM).

For a more detailed analysis, the PSD functions recorded along the exhaust line are provided in Figure 6, together with the corresponding 95\% confidence intervals. The comparison between the PSDs recorded upstream and downstream of the turbine, depicted in Figure 6a, highlights that the finest particles are the most affected by the passage through the turbine. Namely, NM particles increase by about one order of magnitude, while AM particles are little affected. This points out that the increase in total PN (cf. Figure 3), as well as the variation of the relative composition in terms of mode fractions (cf. Figure 5) are exclusively due to an increase of the NM particles downstream of the 
turbine. There are evidences suggesting that nucleation of soluble organic fraction (SOF) is promoted through the turbine [71]. A large share of the SOF is usually related to lubricant oil [46,72,73]; namely, lubricant oil components can represent up to the $80 \%$ of the SOF [74].
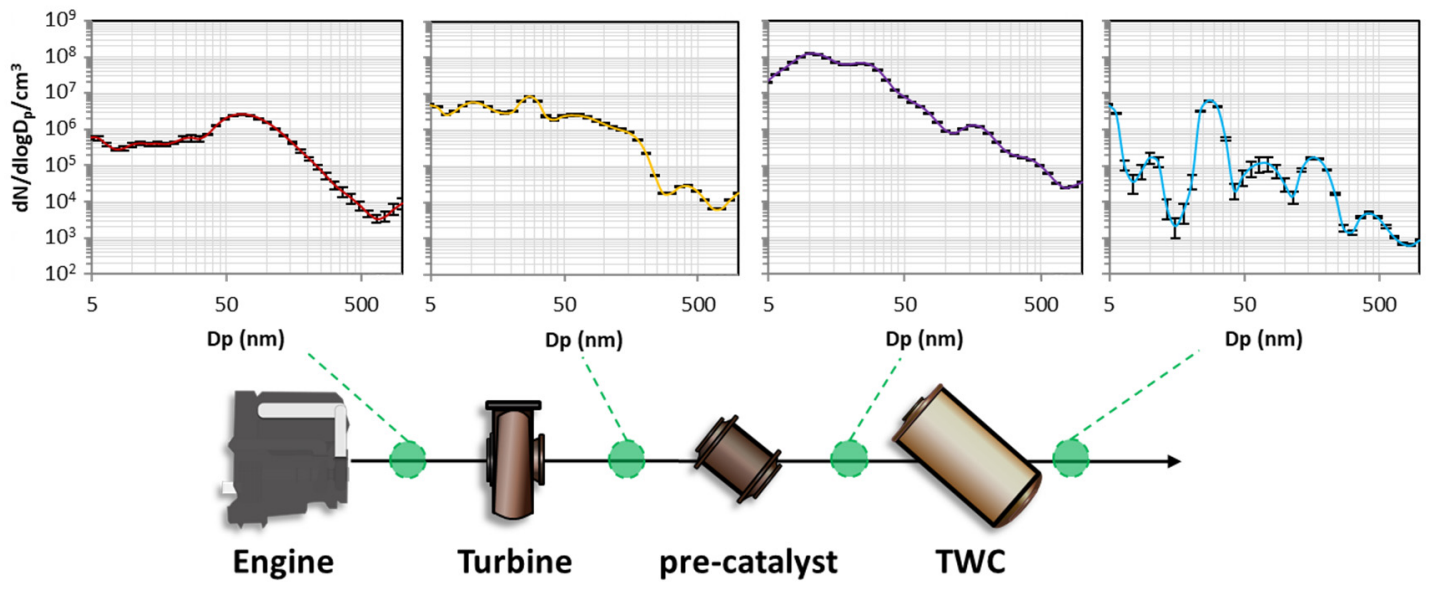

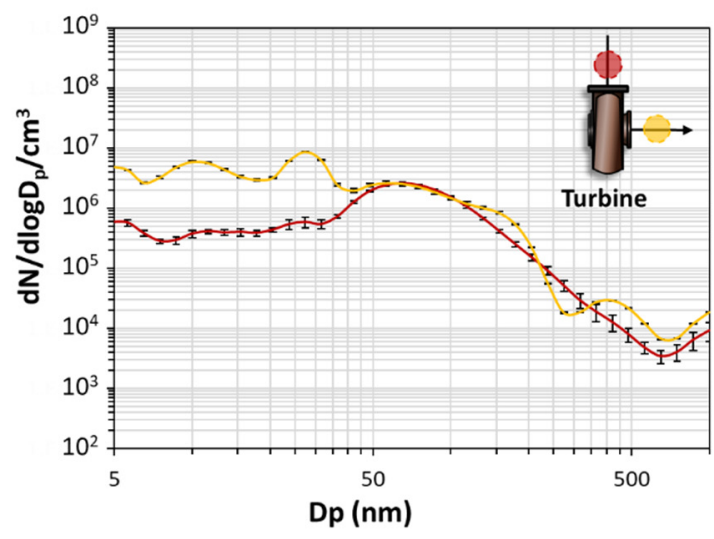

(a)

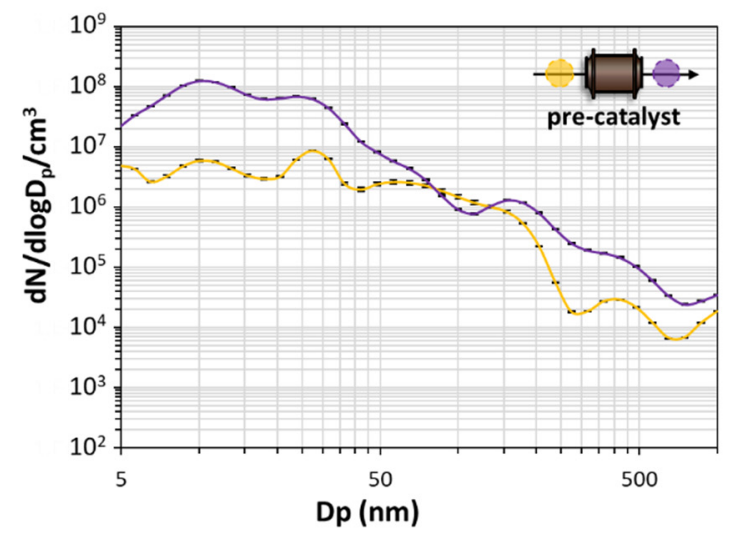

(b)

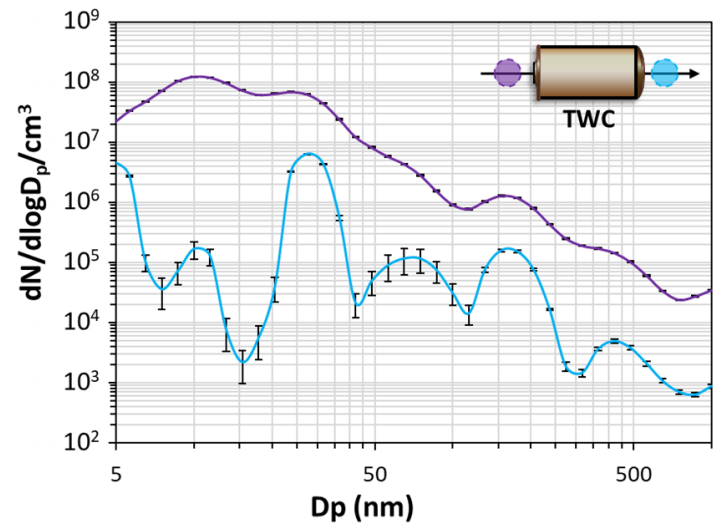

(c)

Figure 6. Particle size distributions (PSDs) along the exhaust line. Comparisons between the PSDs measured upstream and downstream of the turbine (a), the pre-catalyst (b) and the TWC (c).

It is noteworthy that lubricant oil can cause the behavior observed downstream of the turbine in more than one way. Namely, it can penetrate into the combustion chamber following many routes $[75,76]$ 
and contributes to increase these lubricant-related SOF components, which can subsequently coagulate under the turbine action, determining a gas-to-particle conversion. On the other hand, lubricating oil can reach the exhaust stream, for instance escaping from the turbocharger bearings lubricating circuit, and determine a direct increase of the number of the finest particles. There are many studies in which the high emission levels of very fine particles in CNG engines are indirectly associated to lubricant oil $[37,40,51,52,54,77,78]$. In a recent work by Amirante et al. [38], the formation of particles produced solely from lubricant oil was demonstrated by means of experimental tests designed for that very purpose. The results ascertained the concentration number and size distribution of lubricant-oil-derived particles according to the different ways by which the oil escapes from its own circuit. In particular, it was found that lubricant oil contribution is always detectable in the lowest range (never exceeding $30 \mathrm{~nm}$ ), independently of the way it was added, confirming what was supposed and indirectly observed in previous research works.

A possible additional phenomenon that can be generated by the turbine is the fragmentation of some particles due to the interaction with the turbine blades [79]. Fragmentation mainly affects larger particles, which can become detectable by the instrument $[80,81]$, explaining the increase of the particles with size larger than $350 \mathrm{~nm}$ observed in Figure 6a. The increase of the number of particles having such large sizes is also the main cause of the PM increase recorded after the turbine and shown in Figure 4. This aspect is made clearly visible in Figure 7, in which the contributions of NM and AM particles to PM are reported separately and thus their relative importance is ascertained.

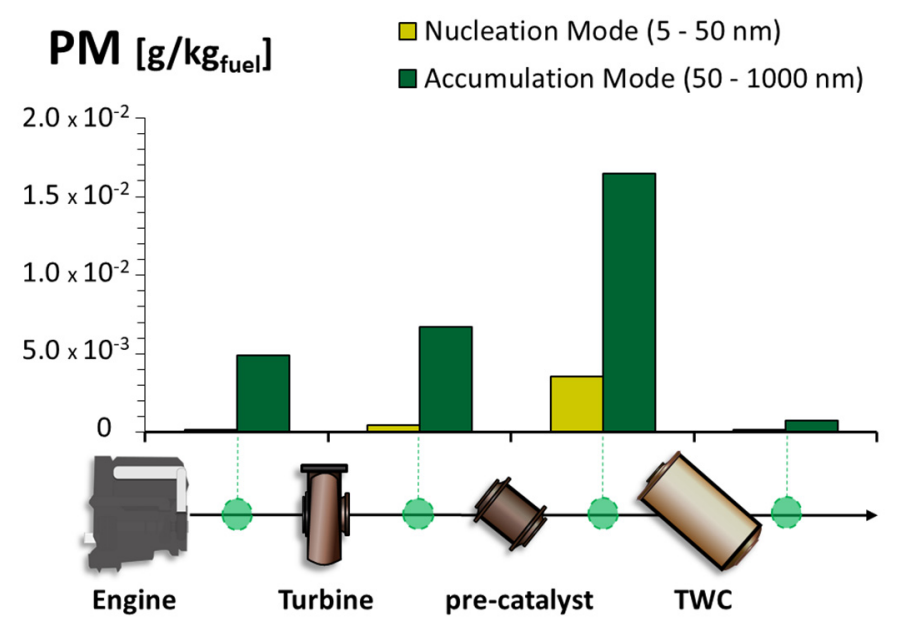

Figure 7. PM decomposition in nucleation mode (NM) and accumulation mode (AM).

Once left the turbine, the exhaust gases encounter the first stage of the after-treatment system. The comparison between the corresponding PSDs recorded downstream of the turbine and the pre-catalyst is provided in Figure 6b. It shows that NM is strongly influenced, as well as the effects on AM particles larger than $100 \mathrm{~nm}$ are not negligible. The number of particles with size ranging from 150 to $1000 \mathrm{~nm}$ reaches the highest level along the exhaust line. PN is increased of averagely one order of magnitude in the size range comprised between 250 and $500 \mathrm{~nm}$ after the passage through the pre-catalyst. The increase of both NM and AM particles explains the further increases in total PN of about one order of magnitude after the pre-catalyst shown in Figure 3. On the whole, the predominance of NM particles is further enhanced, considering that they now account for more than $95 \%$ of the total emitted particles, compared with the $85 \%$ downstream of the turbine, as shown in Figure 5. The non-negligible increase of the number of relatively large AM particles explains the further increase observed in PM as well, as shown in Figure 4.

The simultaneous concurrence of many complex phenomena is at the basis of the simultaneous and significative increase of both PN and PM due to the pre-catalyst. Fragmentation, agglomeration, oxidation and vaporization are all relevant processes occurring in the pre-catalyst $[59,82]$. For instance, 
larger particles suspended into the exhaust gases can undergo fragmentation due the interaction with the internal pre-catalyst structure, determining an increase of the number of smaller particles [60]. At the same time, the passage through the narrow sections of this device forces the particles to collide and bond together, forming larger ones. Moreover, the high temperatures can activate surface oxidation reactions that can significantly contribute to reduce the size of the particles. Simultaneously, the increased temperature can also promote the evaporation of the film that coats some particles, leading to a reduction of their sizes. Thus, a transfer from particle-to-gas phase might be possible in this catalysis stage.

The thermal conditions reigning in this device play the main role in controlling particle transformation processes. Ensuring high working temperatures in the pre-catalyst is essential for a proper operation of both catalysis stages, considering that the pre-catalyst is mainly installed for reducing the light-off time of the TWC and consequently increasing the overall efficiency of the after-treatment system [83]. Figure 8 shows that after the drastic decrease due to the energy extracted by the turbine, the exhaust gases temperature is again significantly increased in the pre-catalyst. On the contrary, a drastic fall of the temperature is recorded after the TWC, indicating that the two after-treatment devices work in different conditions and behave differently with respect to soot emissions. As a consequence, the evolution of soot PN and PM through the after-treatment system appears to be in close correlation with the temperature trend reported in Figure 8.

\section{Temperature $\left[{ }^{\circ} \mathrm{C}\right]$}

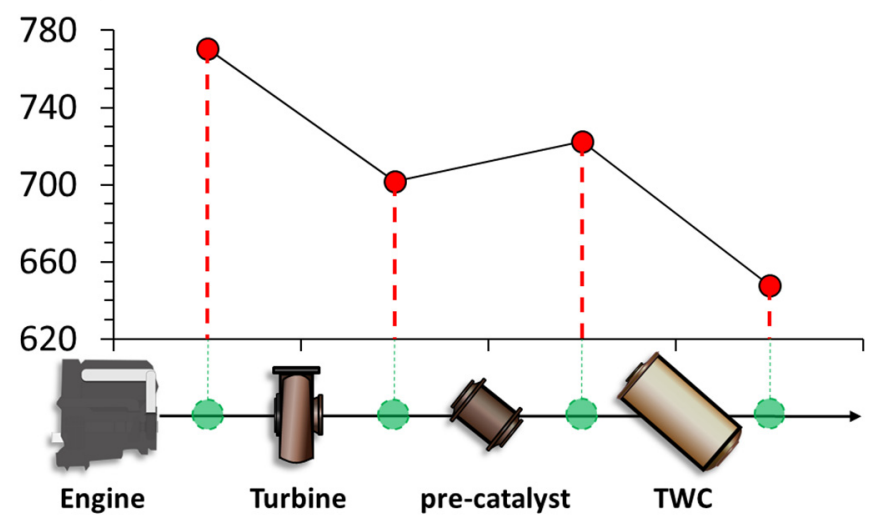

Figure 8. Temperature evolution along the exhaust line.

The significant decrease of total PM downstream of the TWC shown in Figure 4 can be explained considering that processes having a mechanical nature (rather than a thermochemical nature) dominate in this device, due the lower temperatures. The catalyst surfaces in a TWC are extremely porous and can act like a particulate filter, trapping a significant fraction of large particles and contributing to a significant decrease of PM $[59,60,84]$. Moreover, the passage through the TWC enhances the tendency for soot particles to stick together, increasing agglomeration rates and forming larger particles reducing NM particles as well $[57,60]$. Coagulation of liquid components can also be promoted. Figure $6 \mathrm{c}$ indicates that the reduction concerns both $\mathrm{NM}$ and the AM, explaining the simultaneous decrease recorded for total PN (cf. Figure 3).

It is worth noting that the PSD function recorded downstream of the TWC shows the largest variability over time, as can be inferred from the larger width of the error bars obtained at this point of the exhaust line, in comparison to all of the other cases. Moreover, this PSD function presents a less regular trend with respect to the particle size. Several peaks can be observed, with the highest one located between 25 and $30 \mathrm{~nm}$. It is known that soot particles are deposited on catalyst surfaces during the regular engine operation [60]; thus, non-uniform particle release due to occasional breakups of such deposits can explain the larger variability observed after the main catalysis stage. The presence of particle spikes during steady-state measurements are reported in the literature in the case of gasoline 
and CNG spark-ignition engines [64]. This aspect was highlighted in the previous experimental campaign carried out on the same engine [44]. These emission spikes were observed at every operating condition and it was found that they were almost completely composed of nucleation mode particles; furthermore, their magnitude and frequency varied depending on the case. The higher temperature in the pre-catalyst can justify the fact that this behavior is not observed for that device, which shows a much more regular and stable PSD function (cf. Figure 6c). In many research works carried out on CNG engines, ash deposits on the walls of the tailpipes are ascribed to lubricating oil [39]. A transfer from the gas to the particle phase, with nucleation of material mainly constituted by oil additives, might be enhanced after the TWC due to the lower temperatures [29,54,77]. Once formed, these deposits can be stochastically released and emitted by the engine, explaining the less regular PSD function recorded downstream of the TWC. Such a result underlines once more the primary role that lubricant oil can play in determining soot emissions in CNG engines.

\section{Conclusions}

In the present work a detailed experimental characterization of the evolution of total particle number (PN), particle mass (PM) and particle size distributions (PSDs) was provided along the exhaust line of a modern EURO VI compliant turbocharged heavy-duty engine, fueled with compressed natural gas (CNG). Namely, the influence on each of the devices mounted on the engine exhaust line was investigated. Particle samples were collected upstream and downstream of the turbine, the pre-catalyst, and the three-way catalytic converter (TWC). A fast-response differential mobility spectrometer, such as the DMS500, was employed for the analysis. The decomposition of total PN in nucleation mode (NM) and accumulation mode (AM) was also provided.

The highest value of the total PN was recorded downstream of the pre-catalyst, where it was about two orders of magnitude higher than the value recorded at the beginning of the exhaust line, namely, upstream of the turbine. A significative decrease of PN was recorded after the TWC. PM showed a similar trend, progressively increasing until the pre-catalyst, where its highest values were recorded, and then drastically reducing after the passage through the TWC. The fraction of NM particles increased along the exhaust line, from about $40 \%$ upstream of the turbine to more than $90 \%$ downstream of the TWC. The highest value of the NM fraction corresponded to the total PN peak.

It was observed that the turbine produced an increase of the total PN, and this was reasonably attributed to possible induced nucleation of soluble organic fraction components. It has been pointed out that lubricating oil significantly influences this trend in many ways. Moreover, the increase of PM detected downstream of the turbine was attributed to possible fragmentation of very large particles that became detectable by the instrument. The concurrence of various possible phenomena in the pre-catalyst justified the generalized increase recorded, independently of the particle size. Fragmentation, agglomeration, and oxidation compete with each other in the first catalyst stage. On the contrary, the TWC led to a strong reduction of both NM and AM particles, and this was explained considering the temperature reduction and its filtering action.

It has been highlighted that the temperature variations along the exhaust line can play a crucial role in determining the observed particle transformation trends. In fact, it was highlighted that the evolution of PN and PM through the exhaust line was closely correlated to the temperature variations.

Moreover, the occasional release of ash deposits, mainly due to lubricating oil, explained the larger irregularity and variability observed for the PSD function recorded downstream of the TWC. This aspect, together with the above-mentioned ones, highlights the significative role that lubricant oil play in determining soot emissions in CNG engines.

This work represents a first step toward the definition of more complete and accurate analysis procedures, which can help to better understand the formation mechanism of ultrafine soot particles. Future experimental campaigns will deal with analyses carried out in transient conditions as well as with specific tests designed to isolate the sources of ultrafine soot particles (lubricant oil first among them) along the exhaust line of heavy-duty CNG engines. A comparison with samples conditioned 
with a volatile particle remover system will make it possible to analyze the evolution of the particulate volatile organic fraction.

Author Contributions: All the authors (E.D., R.A., G.C., P.D.P., P.T.) performed the experiments, collected and analyzed the data, wrote, edited and revised the manuscript. All authors have read and agreed to the published version of the manuscript.

Funding: This research received no external funding.

Conflicts of Interest: The authors declare no conflicts of interest.

\section{References}

1. Reitz, R.D.; Ogawa, H.; Payri, R.; Fansler, T.; Kokjohn, S.; Moriyoshi, Y.; Agarwal, A.K.; Arcoumanis, D.; Assanis, D.; Bae, C.; et al. IJER editorial: The future of the internal combustion engine. Int. J. Engine Res. 2020. [CrossRef]

2. Kalghatgi, G. Is it really the end of internal combustion engines and petroleum in transport? Appl. Energy 2018, 225, 965-974. [CrossRef]

3. Leach, F.; Kalghatgi, G.; Stone, R.; Miles, P. The scope for improving the efficiency and environmental impact of internal combustion engines. Transp. Eng. 2020, 1, 100005. [CrossRef]

4. Wanitschke, A.; Hoffmann, S. Are battery electric vehicles the future? An uncertainty comparison with hydrogen and combustion engines. Environ. Innov. Soc. Transit. 2019. [CrossRef]

5. Kawamoto, R.; Mochizuki, H.; Moriguchi, Y.; Nakano, T.; Motohashi, M.; Sakai, Y.; Inaba, A. Estimation of $\mathrm{CO} 2$ Emissions of internal combustion engine vehicle and battery electric vehicle using LCA. Sustainability 2019, 11, 2690. [CrossRef]

6. Qiao, Q.; Zhao, F.; Liu, Z.; Jiang, S.; Hao, H. Cradle-to-gate greenhouse gas emissions of battery electric and internal combustion engine vehicles in China. Appl. Energy 2017, 204, 1399-1411. [CrossRef]

7. Requia, W.J.; Mohamed, M.; Higgins, C.D.; Arain, A.; Ferguson, M. How clean are electric vehicles? Evidence-based review of the effects of electric mobility on air pollutants, greenhouse gas emissions and human health. Atmos. Environ. 2018, 185, 64-77. [CrossRef]

8. Senecal, P.K.; Leach, F. Diversity in transportation: Why a mix of propulsion technologies is the way forward for the future fleet. Results Eng. 2019, 4, 100060. [CrossRef]

9. Cotera, P.; Arias, M. The Pathway to Sustainable Transport. In Sustainable Mobility; IntechOpen: London, $\mathrm{UK}, 2020$.

10. Sripad, S.; Viswanathan, V. Performance metrics required of next-generation batteries to make a practical electric semi truck. ACS Energy Lett. 2017, 2, 1669-1673. [CrossRef]

11. Reitz, R.D. Directions in internal combustion engine research. Combust. Flame 2013, 160, 1-8. [CrossRef]

12. Distaso, E.; Amirante, R.; Calò, G.; De Palma, P.; Tamburrano, P.; Reitz, R.D. Predicting Lubricant Oil Induced Pre-Ignition Phenomena in Modern Gasoline Engines: The Reduced GasLube Reaction Mechanism. Fuel 2020, 281, 118709. [CrossRef]

13. Johnson, T.; Joshi, A. Review of vehicle engine efficiency and emissions. SAE Int. J. Engines 2018, 11, 1307-1330. [CrossRef]

14. Distaso, E.; Amirante, R.; Tamburrano, P.; Reitz, R.D. Understanding the role of soot oxidation in gasoline combustion: A numerical study on the effects of oxygen enrichment on particulate mass and number emissions in a spark-ignition engine. Energy Convers. Manag. 2019, 184, 24-39. [CrossRef]

15. Teodosio, L.; Bozza, F.; Tufano, D.; Giannattasio, P.; Distaso, E.; Amirante, R. Impact of the laminar flame speed correlation on the results of a quasi-dimensional combustion model for Spark-Ignition engine. Energy Procedia 2018, 148, 631-638. [CrossRef]

16. Kalghatgi, G.; Johansson, B. Gasoline compression ignition approach to efficient, clean and affordable future engines. Proc. Inst. Mech. Eng. Part D J. Automob. Eng. 2018, 232, 118-138. [CrossRef]

17. Duronio, F.; De Vita, A.; Montanaro, A.; Villante, C. Gasoline direct injection engines-A review of latest technologies and trends. Part 2. Fuel 2020, 265, 116947. [CrossRef]

18. Distaso, E.; Amirante, R.; Cassone, E.; Catapano, F.; De Palma, P.; Sementa, P.; Tamburrano, P. Experimental and Numerical Analysis of a Pre-Chamber Turbulent Jet Ignition Combustion System; SAE Tech. Pap. 2019-24-0018; SAE International: Warrendale, PA, USA, 2019. [CrossRef] 
19. Bhurat, S.S.; Pandey, S.; Chintala, V.; Ranjit, P.S. Technical barriers and their solutions for deployment of HCCI engine technologies-A review. Int. J. Ambient Energy 2019, 1-14. [CrossRef]

20. Robertson, D.; Prucka, R. A Review of Spark-Assisted Compression Ignition (SACI) Research in the Context of Realizing Production Control Strategies; SAE Technical Paper 2019-24-0027; SAE International: Warrendale, PA, USA, 2019.

21. Paykani, A.; Kakaee, A.-H.; Rahnama, P.; Reitz, R.D. Progress and recent trends in reactivity-controlled compression ignition engines. Int. J. Engine Res. 2016, 17, 481-524. [CrossRef]

22. Di Mauro, A.; Chen, H.; Sick, V. Neural network prediction of cycle-to-cycle power variability in a spark-ignited internal combustion engine. Proc. Combust. Inst. 2019, 37, 4937-4944. [CrossRef]

23. Amirante, R.; Coratella, C.; Distaso, E.; Rossini, G.; Tamburrano, P. Optical device for measuring the injectors opening in common rail systems. Int. J. Automot. Technol. 2017, 18, 729-742. [CrossRef]

24. Ravaglioli, V.; Ponti, F.; De Cesare, M.; Stola, F.; Carra, F.; Corti, E. Combustion Indexes for Innovative Combustion Control. SAE Int. J. Engines 2017, 10, 2371-2381. [CrossRef]

25. Amirante, R.; Casavola, C.; Distaso, E.; Tamburrano, P. Towards the Development of the In-Cylinder Pressure Measurement Based on the Strain Gauge Technique for Internal Combustion Engines; SAE Technical Papers 2015-24-2419; SAE International: Warrendale, PA, USA, 2015. [CrossRef]

26. Kuronita, T.; Sakai, T.; Queck, D.; Puts, R.; Visser, S.; Herrmann, O.; Nishijima, Y. A Study of Dynamic Combustion Control for High Efficiency Diesel Engine; SAE Technical Papers 2020-01-0297; SAE International: Warrendale, PA, USA, 2020.

27. Bae, C.; Kim, J. Alternative fuels for internal combustion engines. Proc. Combust. Inst. 2017, 36, $3389-3413$. [CrossRef]

28. Cho, H.M.; He, B.Q. Spark ignition natural gas engines-A review. Energy Convers. Manag. 2007, 48, 608-618. [CrossRef]

29. Amirante, R.; Distaso, E.; Di Iorio, S.; Pettinicchio, D.; Sementa, P.; Tamburrano, P.; Vaglieco, B.M. Experimental Investigations on the Sources of Particulate Emission within a Natural Gas Spark-Ignition Engine; SAE Technical Papers 2017-24-0141; SAE International: Warrendale, PA, USA, 2017. [CrossRef]

30. Distaso, E.; Amirante, R.; Cassone, E.; De Palma, P.; Sementa, P.; Tamburrano, P.; Veglieco, B.M. Analysis of the Combustion Process in a Lean-Burning Turbulent Jet Ignition Engine Fueled with Methane. Energy Convers. Manag. 2020, in press.

31. Amirante, R.; Distaso, E.; Di Iorio, S.; Sementa, P.; Tamburrano, P.; Vaglieco, B.M.; Reitz, R.D. Effects of natural gas composition on performance and regulated, greenhouse gas and particulate emissions in spark-ignition engines. Energy Convers. Manag. 2017, 143, 338-347. [CrossRef]

32. Karavalakis, G.; Hajbabaei, M.; Jiang, Y.; Yang, J.; Johnson, K.C.; Cocker, D.R.; Durbin, T.D. Regulated, greenhouse gas, and particulate emissions from lean-burn and stoichiometric natural gas heavy-duty vehicles on different fuel compositions. Fuel 2016, 175, 146-156. [CrossRef]

33. Amirante, R.; Distaso, E.; Tamburrano, P.; Reitz, R.D. Analytical Correlations for Modeling the Laminar Flame Speed of Natural Gas Surrogate Mixtures. Energy Proc. 2017, 126, 850-857. [CrossRef]

34. McTaggart-Cowan, G.P.; Rogak, S.N.; Munshi, S.R.; Hill, P.G.; Bushe, W.K. The influence of fuel composition on a heavy-duty, natural-gas direct-injection engine. Fuel 2010, 89, 752-759. [CrossRef]

35. Amirante, R.; Distaso, E.; Tamburrano, P.; Reitz, R.D. Laminar Flame Speed Correlations for Methane, Ethane, Propane and their Mixtures, and Natural Gas and Gasoline for Spark-Ignition Engine Simulations. Int. J. Engine Res. 2017, 18, 951-970. [CrossRef]

36. Nylund, N.-O.; Erkkilä, K.; Lappi, M.; Ikonen, M. Transit bus emission study: Comparison of emissions from diesel and natural gas buses. In Proceedings of the IANGVA Conf, Buenos Aires, Argentina, 6-17 December 2004.

37. Jayaratne, E.R.; Meyer, N.K.; Ristovski, Z.D.; Morawska, L.; Miljevic, B. Critical analysis of high particle number emissions from accelerating compressed natural gas buses. Environ. Sci. Technol. 2010, 44, 3724-3731. [CrossRef]

38. Amirante, R.; Distaso, E.; Napolitano, M.; Tamburrano, P.; Iorio, S.D.; Sementa, P.; Vaglieco, B.M.; Reitz, R.D. Effects of lubricant oil on particulate emissions from port-fuel and direct-injection spark-ignition engines. Int. J. Engine Res. 2017, 18, 606-620. [CrossRef] 
39. Jayaratne, E.R.; Meyer, N.K.; Ristovski, Z.D.; Morawska, L. Volatile properties of particles emitted by compressed natural gas and diesel buses during steady-state and transient driving modes. Environ. Sci. Technol. 2012, 46, 196-203. [CrossRef] [PubMed]

40. Alanen, J.; Saukko, E.; Lehtoranta, K.; Murtonen, T.; Timonen, H.; Hillamo, R.; Karjalainen, P.; Kuuluvainen, H.; Harra, J.; Keskinen, J.; et al. The formation and physical properties of the particle emissions from a natural gas engine. Fuel 2015, 162, 155-161. [CrossRef]

41. Hajbabaei, M.; Karavalakis, G.; Johnson, K.C.; Lee, L.; Durbin, T.D. Impact of natural gas fuel composition on criteria, toxic, and particle emissions from transit buses equipped with lean burn and stoichiometric engines. Energy 2013, 62, 425-434. [CrossRef]

42. Bhardawaj, A.; Habib, G.; Kumar, A.; Singh, S.; Nema, A.K. A review of ultrafine particle-related pollution during vehicular motion, health effects and control. J. Environ. Sci. Public Health 2017, 1, 268-288. [CrossRef]

43. Eisazadeh, H.; Ehteram, M.A.; Khazaee, I. Diffusion charging measurements on exhaust solid particle number and lung deposited surface area of compressed natural gas and diesel buses. Environ. Sci. Pollut. Res. 2020, 27, 16929-16939. [CrossRef]

44. Distaso, E.; Amirante, R.; Tamburrano, P.; Reitz, R.D. Steady-state Characterization of Particle Number Emissions from a Heavy-Duty Euro VI Engine Fueled with Compressed Natural Gas. Energy Proc. 2018, 148, 671-678. [CrossRef]

45. Rönkkö, T.; Virtanen, A.; Vaaraslahti, K.; Keskinen, J.; Pirjola, L.; Lappi, M. Effect of dilution conditions and driving parameters on nucleation mode particles in diesel exhaust: Laboratory and on-road study. Atmos. Environ. 2006, 40, 2893-2901. [CrossRef]

46. Lim, M.C.H.; Ayoko, G.A.; Morawska, L.; Ristovski, Z.D.; Jayaratne, E.R. Effect of fuel composition and engine operating conditions on polycyclic aromatic hydrocarbon emissions from a fleet of heavy-duty diesel buses. Atmos. Environ. 2005, 39, 7836-7848. [CrossRef]

47. Qin, J.; Li, X.; Pei, Y. Effects of Combustion Parameters and Lubricating Oil on Particulate Matter Emissions from a Turbo-Charged GDI Engine Fueled with Methanol/Gasoline Blends; SAE Technical Papers; SAE International: Warrendale, PA, USA, 2014. [CrossRef]

48. Singh, A.P.; Pal, A.; Agarwal, A.K. Comparative particulate characteristics of hydrogen, CNG, HCNG, gasoline and diesel fueled engines. Fuel 2016, 185, 491-499. [CrossRef]

49. Adlercreutz, L.; Cronhjort, A.; Stenlaas, O. Particle Emission Measurements in a SI CNG Engine Using Oils with Controlled Ash Content. In Proceedings of the JSAE/SAE Powertrains, Fuels and Lubricants International Meeting, Kyoto, Japan, 26-29 August 2019.

50. Miller, A.L.; Stipe, C.B.; Habjan, M.C.; Ahlstrand, G.G. Role of lubrication oil in particulate emissions from a hydrogen-powered internal combustion engine. Environ. Sci. Technol. 2007, 41, 6828-6835. [CrossRef] [PubMed]

51. Tonegawa, Y.; Oguchi, M.; Tsuchiya, K.; Sasaki, S.; Ohashi, T.; Goto, Y. Evaluation of Regulated Materials and Ultra Fine Particle Emission from Trial Production of Heavy-Duty CNG Engine; SAE Technical Papers; SAE International: Warrendale, PA, USA, 2006. [CrossRef]

52. Amirante, R.; Distaso, E.; Tamburrano, P.; Reitz, R.D. Measured and Predicted Soot Particle Emissions from Natural Gas Engines; SAE Technical Papers 2015-24-2518; SAE International: Warrendale, PA, USA, 2015. [CrossRef]

53. Napolitano, P.; Alfè, M.; Guido, C.; Gargiulo, V.; Fraioli, V.; Beatrice, C. Particle emissions from a HD SI gas engine fueled with LPG and CNG. Fuel 2020, 269, 117439. [CrossRef]

54. Thiruvengadam, A.; Besch, M.C.; Yoon, S.; Collins, J.; Kappanna, H.; Carder, D.K.; Ayala, A.; Herner, J.; Gautam, M. Characterization of particulate matter emissions from a current technology natural gas engine. Environ. Sci. Technol. 2014, 48, 8235-8242. [CrossRef] [PubMed]

55. El-Sherif, A.S. Effects of natural gas composition on the nitrogen oxide, flame structure and burning velocity under laminar premixed flame conditions. Fuel 1998, 77, 1539-1547. [CrossRef]

56. Distaso, E.; Amirante, R.; Calò, G.; De Palma, P.; Tamburrano, P.; Reitz, R.D. Investigation of Lubricant Oil influence on Ignition of Gasoline-like Fuels by a Detailed Reaction Mechanism. Energy Proc. 2018, 148, 663-670. [CrossRef]

57. Liu, H.; Li, Z.; Xu, H.; Ma, X.; Shuai, S. Nucleation mode particle evolution in a gasoline direct injection engine with/without a three-way catalyst converter. Appl. Energy 2020, 259, 114211. [CrossRef] 
58. Lähde, T.; Rönkkö, T.; Virtanen, A.; Schuck, T.J.; Pirjola, L.; Hämeri, K.; Kulmala, M.; Arnold, F.; Rothe, D.; Keskinen, J. Heavy duty diesel engine exhaust aerosol particle and ion measurements. Environ. Sci. Technol. 2009, 43, 163-168. [CrossRef]

59. Whelan, I.; Samuel, S.; Hassaneen, A. Investigation into the role of catalytic converters on tailpipe-out nano-scale particulate matter from gasoline direct injection engine. In Proceedings of the International Powertrains, Fuels \& Lubricants Meeting, San Diego, CA, USA, 25-27 October 2010.

60. Whelan, I.; Timoney, D.; Smith, W.; Samuel, S. The effect of a three-way catalytic converter on particulate matter from a gasoline direct-injection engine during cold-start. SAE Int. J. Engines 2013, 6, 1035-1045. [CrossRef]

61. Maricq, M.M.; Chase, R.E.; Xu, N.; Laing, P.M. The effects of the catalytic converter and fuel sulfur level on motor vehicle particulate matter emissions: Light duty diesel vehicles. Environ. Sci. Technol. 2002, 36, 283-289. [CrossRef]

62. Getsoian, A.B.; Theis, J.R.; Lambert, C.K. Sensitivity of Three-Way Catalyst Light-Off Temperature to Air-Fuel Ratio. Emiss. Control Sci. Technol. 2018, 4, 136-142. [CrossRef]

63. Nakanishi, Y.; Suehiro, Y.; Hashimoto, M.; Narishige, T.; Takeuchi, R.; Shimamoto, Y.; Sano, S.; Iwakura, H. Development of Low Temperature Active Three Way Catalyst. In Proceedings of the WCX SAE World Congress Experience, Detroit, MI, USA, 9-11 April 2019.

64. Graskow, B.R.; Kittelson, D.B.; Abdul-Khalek, I.S.; Ahmadi, M.R.; Morris, J.E. Characterization of Exhaust Particulate Emissions from a Spark Ignition Engine; 980528 SAE Technical Papers; SAE International: Warrendale, PA, USA, 1998.

65. Maricq, M.M.; Xu, N. The effective density and fractal dimension of soot particles from premixed flames and motor vehicle exhaust. J. Aerosol Sci. 2004, 35, 1251-1274. [CrossRef]

66. Park, K.; Cao, F.; Kittelson, D.B.; McMurry, P.H. Relationship between particle mass and mobility for diesel exhaust particles. Environ. Sci. Technol. 2003, 37, 577-583. [CrossRef] [PubMed]

67. Maricq, M.M.; Xu, N.; Chase, R.E. Measuring particulate mass emissions with the electrical low pressure impactor. Aerosol Sci. Technol. 2006, 40, 68-79. [CrossRef]

68. Braun, A.; Huggins, F.E.; Seifert, S.; Ilavsky, J.; Shah, N.; Kelly, K.E.; Sarofim, A.; Huffman, G.P. Size-range analysis of diesel soot with ultra-small angle X-ray scattering. Combust. Flame 2004, 137, 63-72. [CrossRef]

69. Di Stasio, S. Observation of restructuring of nanoparticle soot aggregates in a diffusion flame by static light scattering. J. Aerosol Sci. 2001, 32, 509-524. [CrossRef]

70. Kittelson, D.B.; Watts, W.F.; Johnson, J.P.; Thorne, C.; Higham, C.; Payne, M.; Goodier, S.; Warrens, C.; Preston, H.; Zink, U.; et al. Effect of fuel and lube oil sulfur on the performance of a diesel exhaust gas continuously regenerating trap. Environ. Sci. Technol. 2008, 42, 9276-9282. [CrossRef]

71. Roumeliotis, I.; Mathioudakis, K. Analysis of moisture condensation during air expansion in turbines. Int. J. Refrig. 2006, 29, 1092-1099. [CrossRef]

72. Puzun, A.; Wanchen, S.; Guoliang, L.; Manzhi, T.; Chunjie, L.; Shibao, C. Characteristics of particle size distributions about emissions in a common-rail diesel engine with biodiesel blends. Proc. Environ. Sci. 2011, 11, 1371-1378. [CrossRef]

73. Kim, K.; Si, W.; Jin, D.; Kim, J.-H.; Cho, J.; Baek, S.; Myung, C.-L.; Park, S. Characterization of engine oil additive packages on diesel particulate emissions. J. Mech. Sci. Technol. 2020, 34, 931-939. [CrossRef]

74. Osada, H.; Aoyagi, Y.; Shimada, K.; Akiyama, K.; Goto, Y.; Suzuki, H. SOF component of lubricant oil on diesel PM in a high boosted and cooled EGR engine. In Proceedings of the SAE World Congress \& Exhibition, Detroit, MI, USA, 16-19 April 2007.

75. De Petris, C.; Giglio, V.; Police, G. Some Insights on Mechanisms of Oil Consumption; SAE Technical Papers; SAE International: Warrendale, PA, USA, 1996. [CrossRef]

76. Eastwood, P. Particulate Emissions from Vehicles; John Wiley \& Sons: Hoboken, NJ, USA, 2008; Volume 20.

77. Yoon, S.; Hu, S.; Kado, N.Y.; Thiruvengadam, A.; Collins, J.F.; Gautam, M.; Herner, J.D.; Ayala, A. Chemical and toxicological properties of emissions from CNG transit buses equipped with three-way catalysts compared to lean-burn engines and oxidation catalyst technologies. Atmos. Environ. 2014, 83, 220-228. [CrossRef]

78. Vijayakumar, V.; Tyagi, B.; Mathai, R.; Singh, S.; Sehgal, A.K. Effect of Crankcase Oil on the Particle Size Distribution and Total Number Concentration in a Heavy Duty CNG Engine. In Proceedings of the JSAE/SAE 2015 International Powertrains, Fuels \& Lubricants Meeting, Kyoto, Japan, 1-4 September 2015. 
79. D'Alessio, A.; Barone, A.C.; Cau, R.; D’Anna, A.; Minutolo, P. Surface deposition and coagulation efficiency of combustion generated nanoparticles in the size range from 1 to $10 \mathrm{~nm}$. Proc. Combust. Inst. 2005, 30, 2595-2603. [CrossRef]

80. Cortes, C.; Gil, A. Modeling the gas and particle flow inside cyclone separators. Prog. Energy Combust. Sci. 2007, 33, 409-452. [CrossRef]

81. Cucchi, M.; Samuel, S. Influence of the exhaust gas turbocharger on nano-scale particulate matter emissions from a GDI spark ignition engine. Appl. Therm. Eng. 2015, 76, 167-174. [CrossRef]

82. Marshall, J.S. Particle aggregation and capture by walls in a particulate aerosol channel flow. J. Aerosol Sci. 2007, 38, 333-351. [CrossRef]

83. Samuel, S.; Hassaneen, A.; Morrey, D. Particulate matter emissions and the role of catalytic converter during cold start of GDI engine. In Proceedings of the SAE 2010 Powertrains Fuels \& Lubricants Meeting, San Diego, CA, USA, 25-27 October 2010.

84. Mizuno, T.; Suzuki, J. Development of a new DPNR catalyst. In Proceedings of the SAE 2004 World Congress \& Exhibition, Detroit, MI, USA, 8-11 March 2004.

(C) 2020 by the authors. Licensee MDPI, Basel, Switzerland. This article is an open access article distributed under the terms and conditions of the Creative Commons Attribution (CC BY) license (http://creativecommons.org/licenses/by/4.0/). 